\title{
Isolation of proteins from subacrosomal region of spermatozoa from a marsupial, the tammar wallaby (Macropus eugenii)
}

\author{
M. Lin, X. Zhang, M. Wade, M. Harris and M. Nickel \\ Marsupial Conservation and Management Research Centre, Department of Biological Sciences, University of \\ Newcastle, NSW 2308, Australia
}

\begin{abstract}
Recent studies indicate that subacrosomal proteins are necessary for the attachment of the acrosome onto the nucleus during sperm formation, and for the stability of the nuclear membrane during fertilization. For the first time, subacrosomal proteins have been isolated from a marsupial species, the tammar wallaby (Macropus engenii), using a method developed in our laboratory. Whole ejaculated spermatozoa were fractionated into head and tail sections by ultrasonication to extract subacrosomal proteins. The heads ( $>95 \%$ purity) were then isolated from tail sections using centrifugation with a three-step discontinuous sucrose gradient $(35,68$ and $75 \%(\mathrm{w} / \mathrm{v}))$. The heads were treated with $0.1 \%(\mathrm{v} / \mathrm{v})$ Triton X-100 which stripped off the acrosome, but not the subacrosomal proteins, from the head.

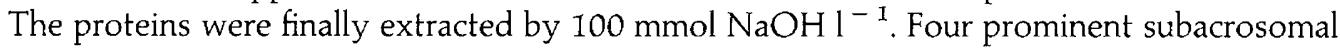
polypeptides, with molecular masses of $45,38,33$ and $29 \mathrm{kDa}$, were recognized from the SDS-PAGE gel. The localization of these polypeptides (particularly the $45 \mathrm{kDa}$ polypeptide) was confirmed by fluorescent and immunogold labelling with polyclonal antibodies raised in mice against the obtained polypeptides. In wallaby testes, the $45 \mathrm{kDa}$ polypeptide was detected as early as at the step 3 spermatid and was mainly associated with the membrane of the newly formed acrosome vesicle. This polypeptide was also found on the acrosomal membrane of all older spermatids. The $45 \mathrm{kDa}$ polypeptide was found on the acrosomal region of the spermatozoa collected from the caput, corpus and cauda of the epididymis. The similarity of the sperm anatomy of the tammar wallaby with that of other marsupials, such as the brushtail possum, implies that this procedure could be applied effectively to other marsupial species with minor modification.
\end{abstract}

\section{Introduction}

In the subacrosomal area of the eutherian spermatozoa, there is a structurally continuous cytoskeletal element, the perinuclear theca, that covers the entire nucleus except in a narrow zone where the sperm tail implants into the base of the nucleus (Lalli and Clermont, 1981; Oko and Clermont, 1988). The perinuclear theca is composed of testicular specific proteins that have little resemblance to the cytoskeletal proteins of the somatic cells. The genes encoding these testicular specific proteins are expressed maximally in round spermatids during spermiogenesis (Longo et al., 1988; van Der Hoorn et al., 1990; Oko and Morales, 1992; Hess et al., 1993; Carrera et al., 1994; Morales et al., 1994; Fulcher et al., 1995). At present, information about the identity of these proteins is very limited. However, it has been confirmed that a $15 \mathrm{kDa}$ perinuclear theca polypeptide in rats (PERF15) belongs to a family of lipid-binding proteins. The protein sequence and intracellular membrane-associated location of PERF15 are homologous to and coincident with that of the myelin P2 protein (Oko and Morales, 1994). The membrane-binding capacity of PERF15 suggests that some

Received 20 August 1997. perinuclear theca proteins are involved in the attachment of the acrosome onto the nucleus during sperm formation and contribute to the stability of the nuclear membrane during fertilization (for review, see Oko, 1995).

Acrosome formation in tammar wallabies (Macropus engenii) and common bushtail possums (Trichosurus vulpecula) is a more complex and lengthy process than it is in many other eutherian mammals (Setiadi et al., 1997). The immature acrosome is still a sheet of folding tissue in a scoop shape when tammar wallaby spermatozoa leave the testis. Some parts of the initial membrane on the lateral projections of the acrosome are engulfed into the acrosomal matrix when the spermatozoa pass through the caput and corpus epididymidis. Within the acrosomal matrix, the subsequent fusion of the infolding membrane persisted when the spermatozoa reached the distal cauda of the epididymis (Lin et al., 1997a). Therefore, in tammar wallabies, the final composition of the acrosome membrane proteins, which includes proteins in the subacrosomal region, is a result of a remarkable reorganization of the acrosome during sperm maturation in the epididymis.

The existence of the perinuclear theca and its biochemical compositions have not been investigated previously in marsupials. Although a structure homologous to that of eutherian 


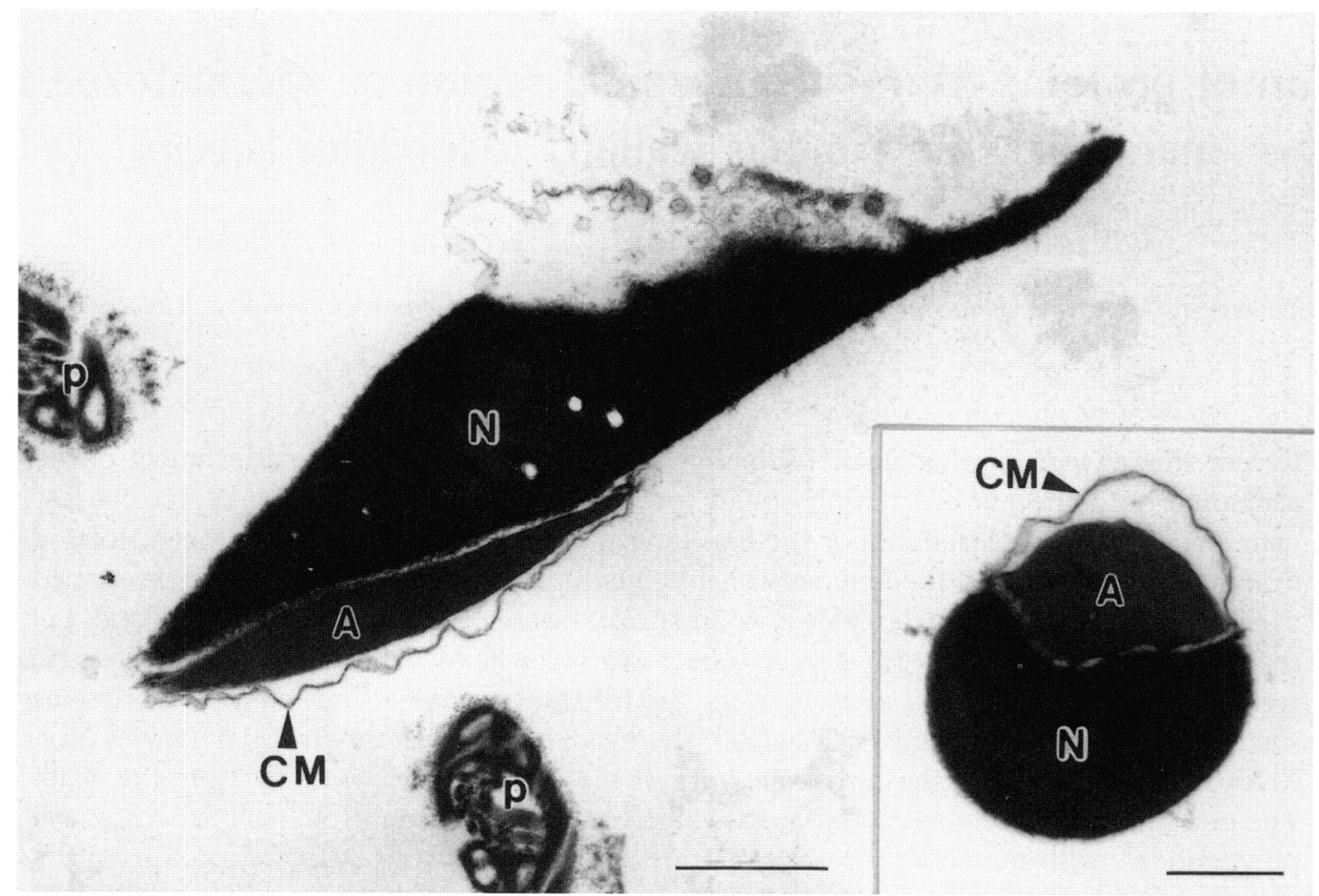

Fig. 1. Electron micrographs of a longitudinal section and a cross-section (insert) of a tammar wallaby sperm head after sonication treatment. Note the acrosome $(A)$ and the cytoplasmic membrane $(C M)$ on its surface are still intact, while the cytoplasmic membrane on other region of the nucleus $(\mathrm{N})$ was stripped off by the sonication. $\mathrm{P}$, principal piece of the sperm flagellum. Scale bars represent $1 \mu \mathrm{m}$ and $0.4 \mu \mathrm{m}$ (insert).

perinuclear theca does exist in marsupial spermatozoa, use of the term 'perinuclear theca' remains questionable in most marsupial species, in which the acrosome is positioned only on the anterior end of the dorsal face of the sperm head (Harding ef al., 1979, 1982; Temple-Smith, 1987; Bedford, 1991; Lin et al., 1997b). The asymmetrical location of the acrosome on the nucleus and the relatively small nuclear attachment area of the acrosome in marsupial spermatozoa suggest that the proteins located in the subacrosomal region are more critical for the attachment of the acrosome to the nucleus than they are in eutherian spermatozoa.

This study used cellular fractionation to extract sperm proteins from the subacrosomal region of tammar wallaby spermatozoa, and used immunofluorescence and immunogold labelling to demonstrate the subacrosomal location of the proteins obtained. The objective of the study was to provide a basis for further characterization of these proteins and understanding of their roles in acrosome formation and fertilization in marsupials.

\section{Materials and Methods}

\section{Animals}

A pool of adult male tammar wallabies (Macropus eugenii) was obtained from Kangaroo Island, South Australia, and maintained on a diet of kangaroo pellets, Lucerne hay, grasses and a fresh supply of water in the holding yards of the Central Animal House at the University of Newcastle, New South
Wales. These animals had all been used as semen donors, and were known to have recently produced ejaculates containing large numbers of highly motile spermatozoa.

Inbred female Balb/c mice (6-12 weeks) were used for the production of polyclonal antibodies to sperm proteins. The animals were fed on a diet of mouse pellets and water ad libitum.

The use of protected animals and animal experimentation were approved by the appropriate state authorities and by the Animal Care and Ethics Committee of the University of Newcastle, respectively.

\section{Fractionation of tammar wallaby spermatozoa}

Tammar wallaby semen was collected by electroejaculation, allowed to coagulate and the spermatozoa were obtained by 'swim-up' into 10-20 ml Tris buffered saline (TBS, pH 7.4; Mate and Rodger, 1991). The spermatozoa were pelleted by centrifugation at approximately $750 \mathrm{~g}$ for $10 \mathrm{~min}$. The pellet was washed twice in TBS by the same centrifugation as above. The washed spermatozoa were resuspended in TBS containing 0.1 mol phenylmethylsulfonyl fluoride $1^{-1}$ (PMSF) and protease inhibitor cocktail (10 mmol EDTA ${ }^{-1}, 0.35 \mathrm{mmol}$ iodoacetamide $\mathrm{I}^{-1}, 2 \mu \mathrm{g}$ antipain $\mathrm{ml}^{-1}, 10 \mu \mathrm{g}$ benzamidine $\mathrm{ml}^{-1}$ and $1 \mu \mathrm{g}$ pepstatin $\mathrm{ml}^{-1}$ ). Fractionation of the spermatozoa was carried out by a Branson 450 Sonifier (Branson, Danbury, $\mathrm{CT}$ ) using a force of $25 \mathrm{~W}$ with 0.6 pulses $\mathrm{s}^{-1}$ for $2 \times 10 \mathrm{~s}$ on ice. The effects of the fractionation were monitored by phase contrast microscopy and electron microscopy. After sonication, 


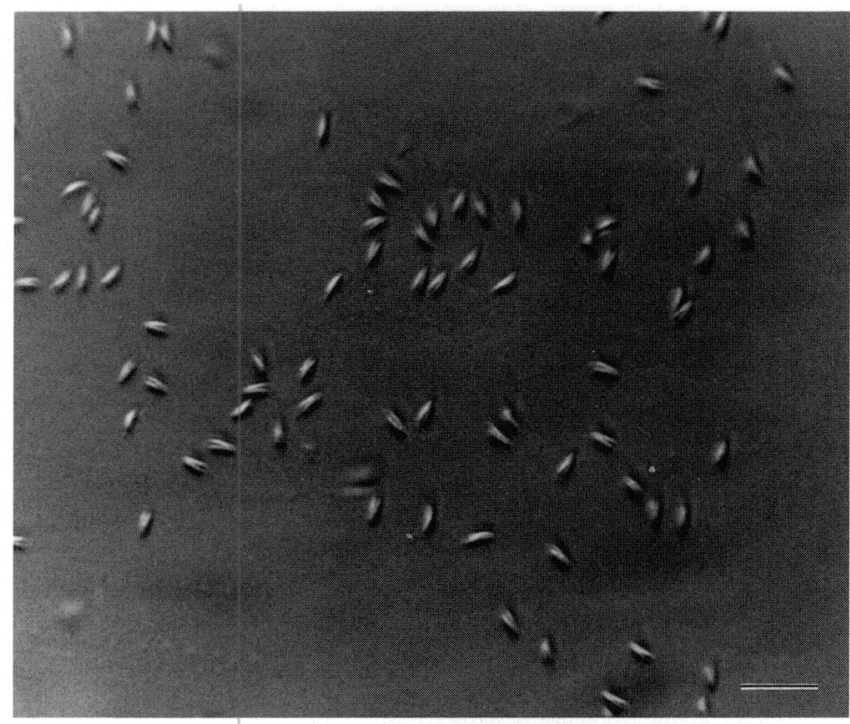

Fig. 2. Light micrograph of isolated tammar wallaby sperm heads recovered from the $75 \%(\mathrm{w} / \mathrm{v})$ sucrose layer after centrifugation and free of significant contamination by the sperm flagella. Scale bar represents $4 \mu \mathrm{m}$.

the sperm fractions were pelleted by centrifuging at approximately $320 \mathrm{~g}$ for $10 \mathrm{~min}$, and then resuspended in $35 \%(\mathrm{w} / \mathrm{v})$ sucrose in TBS for isolation of the sperm heads.

\section{Isolation of sperm heads}

Two millilitres of the $35 \%(w / v)$ sucrose containing resuspended sperm fractions were layered over a $68 \%(w / v)$ and $75 \%(w / v)$ sucrose $(4 \mathrm{ml}$ for each layer) gradient buffered in 0.25 mmol Tris- $\mathrm{HCl}$ with PMSF $1^{-1}(\mathrm{pH} 7.5)$ and centrifuged at $5200 \mathrm{~g}$ for $30 \mathrm{~min}$ at $4^{\circ} \mathrm{C}$. The isolated sperm heads were recovered from the pellet in the $75 \%(\mathrm{w} / \mathrm{v})$ sucrose layer and resuspended in TBS. The purity (\%) of the sperm heads was assessed by phase-contrast microscopy, and the ultrastructure was observed under an electron microscope.

\section{Isolation of subacrosomal proteins}

After the assessment of purity, the sperm heads were pelleted and resuspended in $2 \mathrm{ml} 0.1 \%(\mathrm{v} / \mathrm{v})$ Triton X-100 in TBS for $60 \mathrm{~min}$ on ice to detach the acrosome and the plasma membrane. At the end of the Triton X-100 incubation, the sperm heads were pelleted by centrifugation at $1350 \mathrm{~g}$ for $10 \mathrm{~min}$. The supernatant containing the contents of acrosome and sperm plasmalemma attached to the outer acrosome membrane was collected into a dialysis tube $(6 \mathrm{~mm}$, SigmaAldrich, Castle Hill, NSW) for dialysis. The sperm head pellet was resuspended in $2 \mathrm{ml}$ of $100 \mathrm{mmol} \mathrm{NaOH} \mathrm{l} \mathrm{I}^{-1}$ for $30 \mathrm{~min}$ on ice to extract subacrosomal proteins. After the $\mathrm{NaOH}$ treatment, the sperm nuclei were pelleted by centrifugation at $1350 \mathrm{~g}$ for $10 \mathrm{~min}$. The extract of the subacrosomal proteins was collected into dialysis tubing and dialysed through six changes of Milli-Q water over $48 \mathrm{~h}$. The extract was then frozen, lyophilized and stored in the freezer before electrophoresis.
The sperm flagella collected from the sucrose gradient were treated with $0.1 \%(\mathrm{v} / \mathrm{v})$ Triton $X-100$ in TBS for $60 \mathrm{~min}$ on ice for comparison. It was presumed that the supernatant contained surface proteins of the flagella and these were collected for protein dialysis, lyophilization and SDS-PAGE analysis.

\section{SDS-PAGE}

The lyophilized protein extracts were solublized in a sample buffer consisting of $2 \%(\mathrm{w} / \mathrm{v})$ SDS, $5 \%(\mathrm{v} / \mathrm{v})$ $2 \beta$-mercaptoethanol, $10 \%(\mathrm{v} / \mathrm{v})$ glycerol and $0.0013 \%(\mathrm{w} / \mathrm{v})$ bromophenol blue at $95^{\circ} \mathrm{C}$ for $4 \mathrm{~min}$. About $10-15 \mu \mathrm{l}$ of each sample containing approximately $20-30 \mu \mathrm{g}$ of the protein was run on discontinuous polyacrylamide gel (a $6 \%(\mathrm{w} / \mathrm{v})$ stacking gel and a $12 \%(\mathrm{w} / \mathrm{v})$ separating gel) in a Mini-PROTEAN II electrophoresis cell (BIO-RAD, Sydney) according to the SDS-discontinuous system described by Laemmli (1970). The gel was run at a constant voltage of $200 \mathrm{~V}$ for approximately $40 \mathrm{~min}$, stained with $0.1 \%(\mathrm{w} / \mathrm{v})$ Coomassie brilliant blue R-250 for $30 \mathrm{~min}$ and de-stained in fixative $(40 \%(\mathrm{v} / \mathrm{v})$ methanol, $10 \%$ $(\mathrm{v} / \mathrm{v})$ acetic acid) for $1-3 \mathrm{~h}$ until protein bands could be visualized. The molecular mass of the extracted proteins was determined from the mobility of the SDS-PAGE Broad Range Standards (BIO-RAD). Polypeptide bands on the gel were excised and immediately lyophilized overnight for antibody preparations.

\section{Preparation of polyclonal antibody against the $45 \mathrm{kDa}$ polypeptide}

The $45 \mathrm{kDa}$ polypeptide band was cut from the acrylamide gel and lyophilized overnight. Each time, 5-10 gel bands (approximately 4-7 $\mu \mathrm{g}$ polypeptide) were re-hydrated with $250 \mu \mathrm{l}$ of sterile PBS, and then emulsified in an equal volume of complete Freund's adjuvant (CFA) within a sterile Leur-lock syringe. A volume of $300 \mu \mathrm{l}$ protein-CFA mix was injected i.p. into a Balb/c mouse after collecting the control serum from the retro-orbital sinus vein. The animal was boosted with the same volume of protein-incomplete Freund's adjuvant emulsion 3 weeks later. Collection of the antiserum started from 10-14 days after the primary immunization or the second boost. The serum was frozen at $-20^{\circ} \mathrm{C}$ after being diluted 1:50 with sterile PBS with $0.02 \%(w / v)$ sodium azide, ready for tests of specificity by immunoblotting and immunocytochemistry. The antibody in the serum was examined by indirect immunofluorescence (see below). A third boost was given if the antibody was too low to be detected by immunofluorescence.

\section{Western blotting}

Subacrosomal proteins from $\mathrm{NaOH}$ extracts were run on SDS-PAGE as described above, and transferred electrophoretically from the gel to nitrocellulose or polyvinylidene diflouride (PVDF) membrane $(0.2 \mu \mathrm{m}$ pore size; BIO-RAD, Hercules, CA). The PVDF membrane was soaked first in absolute methanol for 2-3 min before transfer, and then in a transfer buffer composed of 25 Tris-base, $192 \mathrm{mmol}_{\text {glycine }} \mathrm{l}^{-1}$ and $20 \%$ methanol (v/v, $\mathrm{pH} 8.3$ ) for $20 \mathrm{~min}$. The SDS-PAGE gels were equilibrated in the transfer buffer for $10 \mathrm{~min}$. Electrophoretic transfer was run at about $40 \mathrm{~mA}(30 \mathrm{~V})$ overnight at $4^{\circ} \mathrm{C}$. After transfer, the 


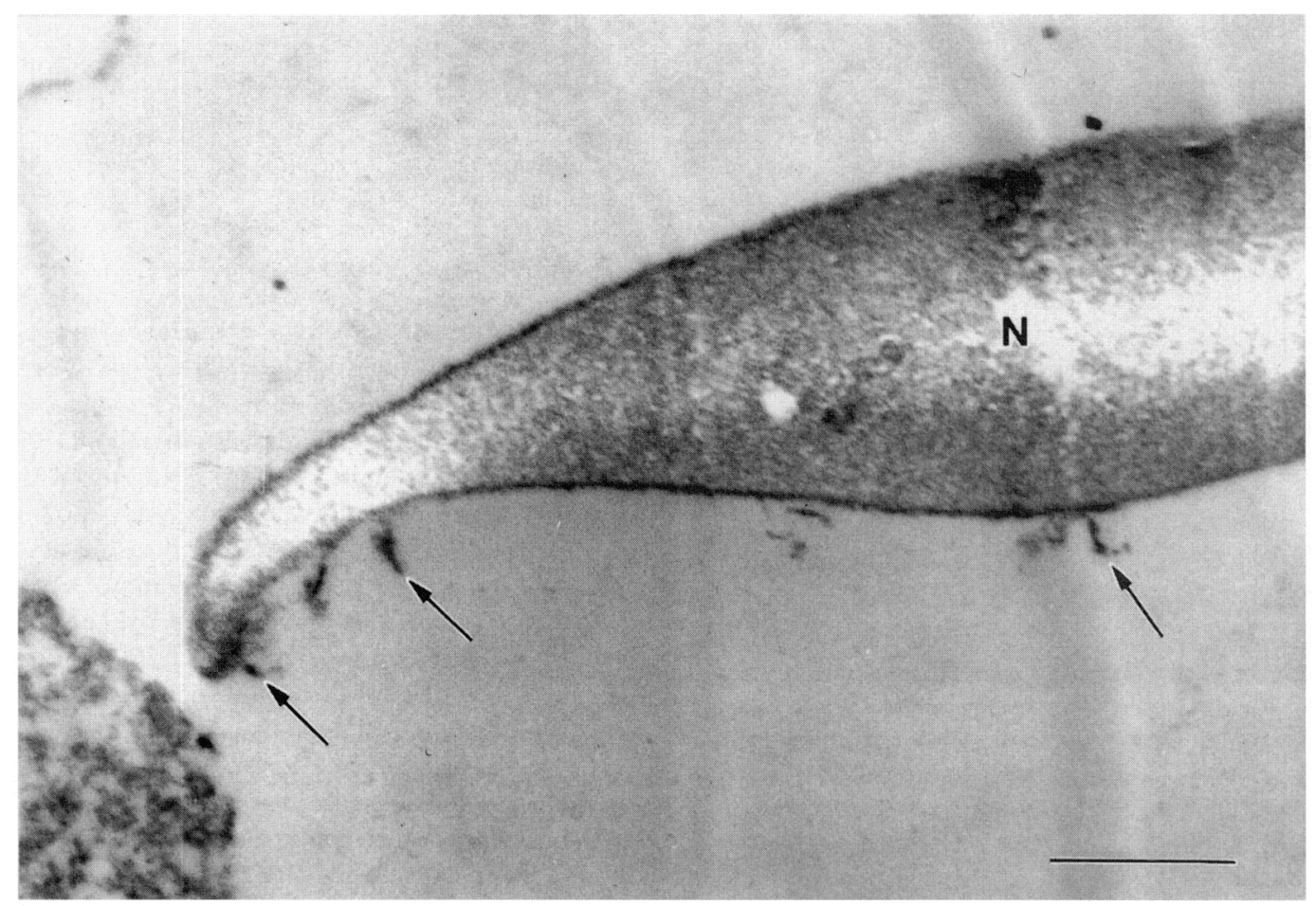

Fig. 3. Electron micrograph of a longitudinal section of a tammar wallaby spermatozoon after Triton X-100 incubation. The acrosome was detached from the nucleus $(\mathrm{N})$. However, the subacrosomal protein remnants (arrows) remained on the nuclear membrane. Scale bar represents $0.5 \mu \mathrm{m}$.

membrane was stained with $0.2 \%(\mathrm{w} / \mathrm{v})$ Ponceau S (3-hydroxy4-(2-sulpho-4-(sulpho-phenylazo) phenylazp)-2,7-naphthalene disulphonic acid) in $3 \%(\mathrm{v} / \mathrm{v})$ trichloroacetic acid until the standards and protein bands were observed. Once the standards and protein bands were visible on the membrane, the standards were cut out and kept for markers of molecular masses. The membrane was completely de-stained in TBS, and then saturated with $3 \%(\mathrm{w} / \mathrm{v}) \mathrm{BSA}$ in $20 \mathrm{mmol}$ Tris- $\mathrm{HCl} 1^{-1}$, $150 \mathrm{mmol} \mathrm{NaCl} \mathrm{I}{ }^{-1}$ and $0.05 \%(\mathrm{w} / \mathrm{v}$ ) Tween 20 (TBST, pH 7.5) for $60 \mathrm{~min}$. The selected lanes on the membrane were stripped and incubated with 1:2000 polyclonal antibodies against the $45 \mathrm{kDa}$ polypeptide or control serum for $60 \mathrm{~min}$ at room temperature. The strips were washed three times in TBS for 10 min each before being incubated with a secondary antibody (1:30 000 diluted alkaline phosphatase-conjugated goat antimouse IgG; Sigma Immuno Chemicals, St. Louis, MO) for $30 \mathrm{~min}$ at room temperature. After incubation, the strips were washed three times in TBST for $10 \mathrm{~min}$ each and twice in TBS briefly. Protein bands were detected on the strips by adding western blue stabilized substrate (Promega Corporation, Madison, WI) to develop the alkaline phosphatase reaction. The reaction was stopped by rinsing twice in Milli-Q water. The strips were dried on filter paper ready to be photographed.

\section{Preparation for indirect immunofluorescence}

Fresh electroejaculated wallaby spermatozoa were washed by 'swim-up' and pelleted by centrifugation at $800 \mathrm{~g}$ for
$10 \mathrm{~min}$. The spermatozoa were fixed by resuspension in $4 \%$ $(\mathrm{w} / \mathrm{v})$ paraformaldehyde in PBS $(\mathrm{pH} 7.4)$ for $20 \mathrm{~min}$, and pelleted again by centrifugation at $600 \mathrm{~g}$ for $10 \mathrm{~min}$. The sperm pellet was then resuspended in PBS containing $50 \mathrm{mmol}$ glycine $1^{-1}$ and $0.02 \%(\mathrm{w} / \mathrm{v}) \mathrm{NaN}_{3}$, and diluted to a concentration of approximate $10^{6}$ spermatozoa $\mathrm{ml}^{-1}$.

Acrosome-detached spermatozoa were prepared to expose the subacrosomal region for the immunofluorescence. The 'swim-up' wallaby spermatozoa were pelleted by centrifugation at $800 \mathrm{~g}$ for $10 \mathrm{~min}$ and resuspended in $0.1 \%(\mathrm{w} / \mathrm{v})$ Triton $\mathrm{X}-100$ for $1 \mathrm{~h}$ on ice to strip off the plasma membrane and to detach the acrosome.

The acrosome-detached spermatozoa were washed twice by centrifugation and resuspension in PBS, and then the same procedure of fixation as described above for the fresh ejaculated spermatozoa was followed.

The tissues were fixed in Bouin's fluid overnight and embedded into paraffin wax in preparation for immunofluorescence of the testis and epididymis. Sections of 5-7 $\mu \mathrm{m}$ were cut and mounted on glass slides. The sections were deparaffined and rehydrated, and then the indirect immunofluorescent procedure described below was followed.

About $50-100 \mu \mathrm{l}$ of the glycine-treated spermatozoa were settled onto a poly-L-lysine-coated coverslip placed within a humid chamber for $2 \mathrm{~h}$ at $37^{\circ} \mathrm{C}$. After a brief wash in PBS, the spermatozoa and tissues of the testis and epididymis were blocked with $3 \%(\mathrm{w} / \mathrm{v}) \mathrm{BSA}$ in PBS for $2 \mathrm{~h}$ at $37^{\circ} \mathrm{C}$. The samples were washed in PBS and then incubated in $50 \mu \mathrm{l}$ of 1:1000 to $1: 5000$ anti-45 $\mathrm{kDa}$ polyclonal antibody or control serum in PBS for $2 \mathrm{~h}$ at $37^{\circ} \mathrm{C}$ with $95 \%(\mathrm{v} / \mathrm{v})$ air and $5 \%(\mathrm{v} / \mathrm{v})$ 


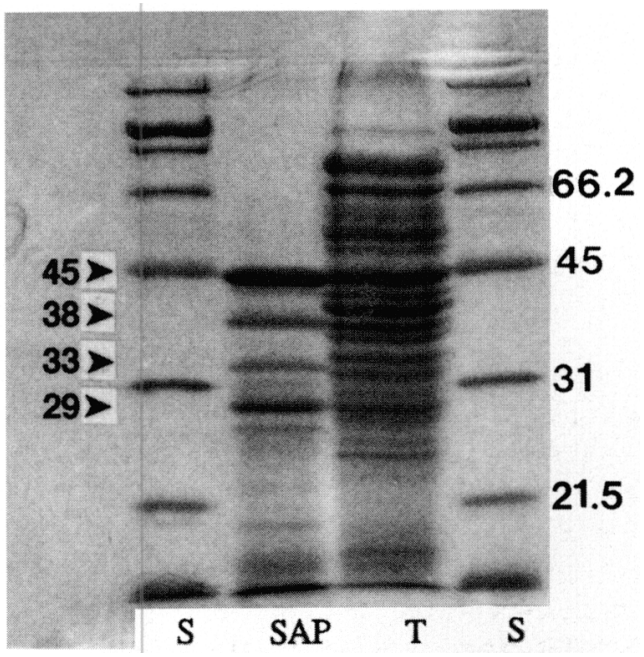

Fig. 4. SDS-PAGE gel shows four prominent bands of the subacrosomal polypeptides (lane SAP) with molecular masses of $45,38,33$ and $29 \mathrm{kDa}$, respectively, extracted from tammar wallaby sperm heads by the $\mathrm{NaOH}$ extraction. Lane $\mathrm{T}$ shows polypeptide bands of the sperm flagella from Triton X-100 extraction. Lane S shows molecular mass standards

$\mathrm{CO}_{2}$. After three washes in PBS of 10 min each, the examples were incubated in $50 \mu \mathrm{l}$ fluorescein isothiocyanate (FITC) conjugated sheep anti-mouse $\operatorname{IgG}$ at $37^{\circ} \mathrm{C}$ for $45 \mathrm{~min}$. After four washes in PBS of 10 min each, the spermatozoa on the coverslips were rinsed quickly in distilled water and then mounted on an ethanol washed slide with Mowiol (CALBIOCHEM, La Jolla, CA). The slides of spermatozoa and tissues were set overnight at $4^{\circ} \mathrm{C}$ and examined using a Microstar IV or Zeiss fluorescence microscope.

\section{Preparation for the electron microscopy}

The morphological changes in each step of the sperm fractionation and the protein extraction were monitored by transmission electron microscopy. Sperm samples were fixed with $2.5 \%(\mathrm{v} / \mathrm{v})$ glutaraldehyde and $2 \%(\mathrm{w} / \mathrm{v})$ paraformaldehyde in $0.1 \mathrm{~mol} \mathrm{^{-1 }}$ cacodylate buffer overnight at $4^{\circ} \mathrm{C}$, and then post-fixed in $1 \%(\mathrm{w} / \mathrm{v}) \mathrm{O}_{\mathrm{S}} \mathrm{O}_{4}$ for $1 \mathrm{~h}$ at room temperature. The samples were dehydrated in a graded series of acetone solutions and then embedded in Spurr's resin (Agar Scientific Ltd, Stansted, Essex). Sections of $70-80 \mathrm{~nm}$ were cut on an Ultracut $S$ ultramicrotome (Reichert-Jung, Hernalser Haupster) using a diamond knife (Diatome Ltd, Bienne, Switzerland) and stained with $1 \%(\mathrm{w} / \mathrm{v})$ uranyl acetate in $30 \%(\mathrm{v} / \mathrm{v})$ ethanol and then a lead citrate solution. Sections were examined and photographed using a JOEL-100CX transmission electron microscope (JOEL, Tokyo) operating at $80 \mathrm{kV}$.

\section{Preparation for immunogold labelling}

A pre-embedding immunogold labelling method was used to localize the isolated subacrosomal proteins at the ultrastructural level. The fresh swim-up spermatozoa were treated with $0.1 \%(\mathrm{v} / \mathrm{v})$ Triton X-100 for $30 \mathrm{~min}$ on ice to detach the acrosome and expose the subacrosomal proteins for the immu-

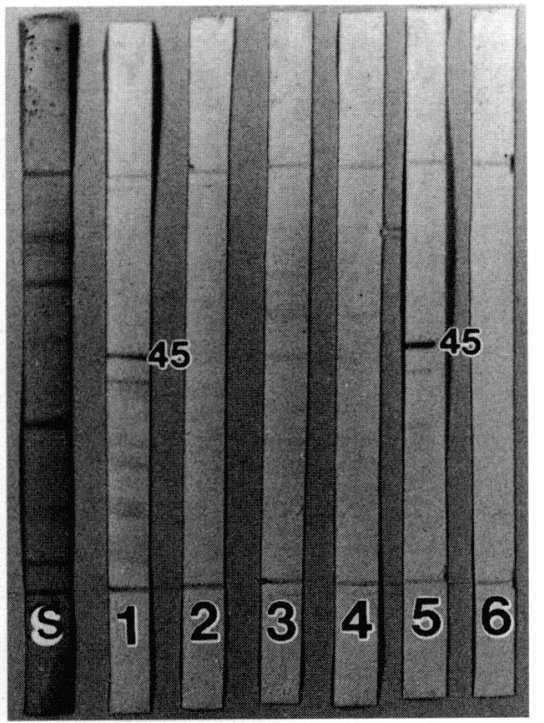

Fig. 5. Western blot analysis of extracted tammar wallaby sperm proteins immunostained with antibody against the $45 \mathrm{kDa}$ subacrosomal polypeptide (lanes 1, 3 and 5), and with pre-immune control serum (lanes 2, 4 and 6). Lanes 1 and 2 are subacrosomal proteins from $\mathrm{NaOH}$ extraction. Lanes 3 and 4 are sperm tail proteins from Triton $X-100$ extraction. Lanes 5 and 6 are acrosomal and cytoplasmic membrane proteins from Triton $X-100$ extraction during the process of acrosome detachment. Lane $S$ shows protein molecular weight standards.

nogold labelling. The Triton X-100-treated spermatozoa were washed in PBS for $5 \mathrm{~min}$ and then fixed with $4 \%(\mathrm{w} / \mathrm{v})$ paraformaldehyde in $0.1 \mathrm{~mol}$ phosphate buffer $\mathrm{l}^{-1}$ for $20 \mathrm{~min}$ at room temperature. The paraformaldehyde-fixed spermatozoa were pelleted and washed twice $(5 \mathrm{~min}$ each) with $50 \mathrm{mmol}$ glycine-PBS $1^{-1}$. The glycine-treated spermatozoa were blocked with $3 \%(\mathrm{w} / \mathrm{v}) \mathrm{BSA}$ in incubation buffer $(150 \mathrm{mmol}$ $\mathrm{NaCl} \mathrm{l} 1^{-1}, 20 \mathrm{mmol} \mathrm{NaN}_{3} \mathrm{I}^{-1}$ in $10 \mathrm{mmol}$ phosphate $\mathrm{l}^{-1}, \mathrm{pH}$ 7.6) for $30 \mathrm{~min}$ and then incubated with $1: 50$ or 1:100 diluted anti- $45 \mathrm{kDa}$ polypeptide and control serum in incubation buffer for $60 \mathrm{~min}$ at room temperature. After three washes $(5 \mathrm{~min}$ each) with incubation buffer, the spermatozoa were incubated with 1:20 diluted $5 \mathrm{nmol}$ immunogold reagent $\mathrm{I}^{-1}$ (goat-antimouse, IgG + IgM; Nanoprobes, Stony Brook, NY) in incubation buffer for $90 \mathrm{~min}$ at room temperature. At the end of the incubation, the spermatozoa were washed three times $(5 \mathrm{~min}$ each) with incubation buffer, and then fixed in $1 \%(\mathrm{w} / \mathrm{v})$ paraformaldehyde and $2.5 \%(\mathrm{v} / \mathrm{v})$ glutaraldehyde in $0.1 \mathrm{~mol}$ PBS $1^{-1}$ overnight at $4^{\circ} \mathrm{C}$. The spermatozoa were embedded in Spurr's resin and processed for electron microscopic observation according to the procedure described above.

\section{Results}

\section{Fractionation of tammar wallaby spermatozoa}

After the sonication treatment, $>95 \%$ of the wallaby spermatozoa were decapitated, while $>90 \%$ of separated sperm heads retained their acrosome. Electron microscopy confirmed that the acrosome was still attached to the nucleus of 

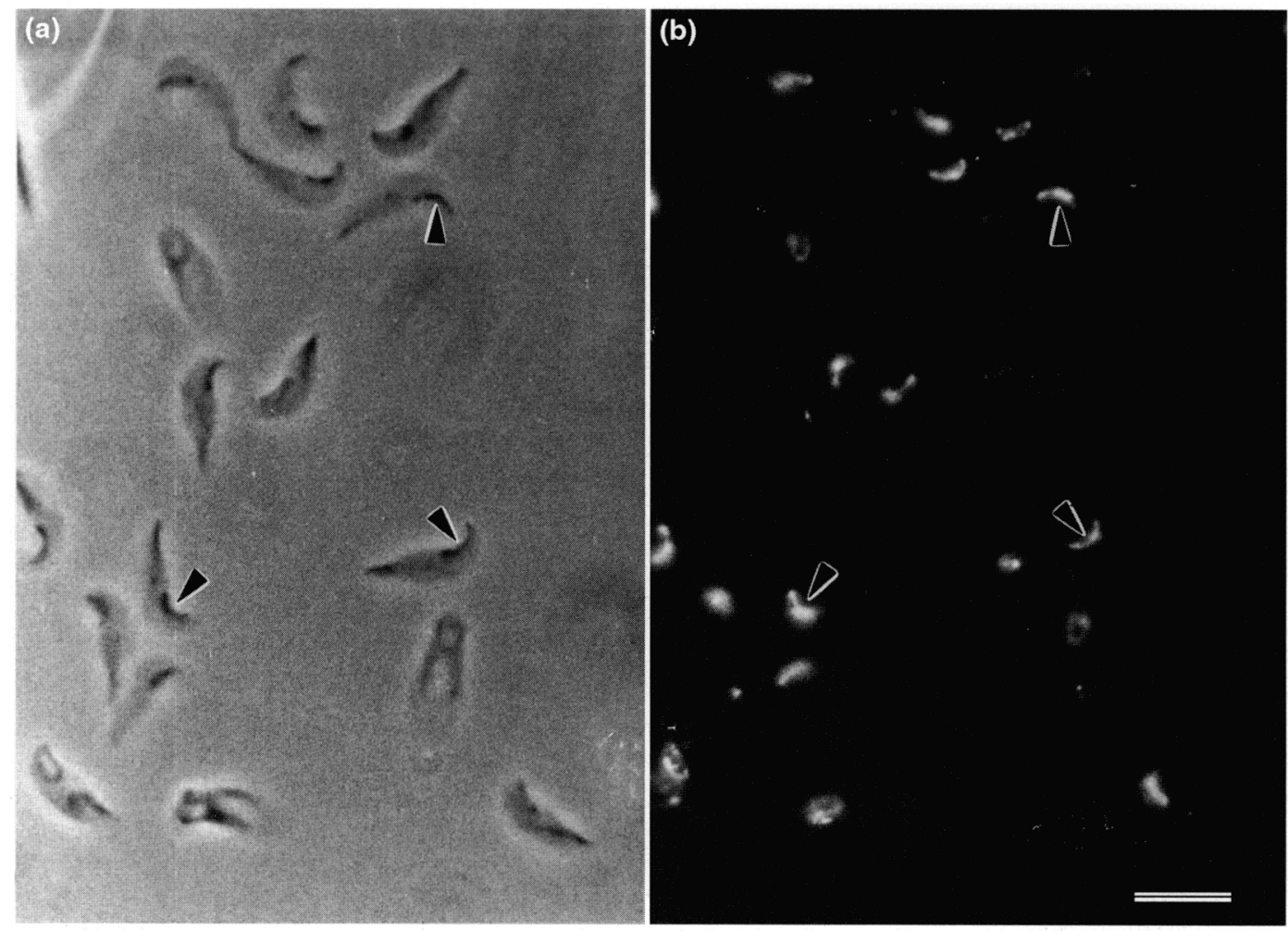

Fig. 6. Light micrographs of tammar wallaby sperm heads from which the acrosomes have been detached after Triton X-100 incubation. (a) Phase-contrast micrograph showing the subacrosomal region (arrowheads) exposed as a result of the acrosome detachment. (b) Fluorescent micrograph showing labelling of the antibody against $45 \mathrm{kDa}$ polypeptide to be exactly located on the subacrosomal region (arrowheads) of the nucleus. Scale bar represents $2 \mu \mathrm{m}$.

the sperm heads (Fig. 1). The sperm plasmalemma overlying the acrosome was also retained, though the sperm plasmalemma on other regions of the spermatozoa had been stripped off during the process of sonication (Fig. 1).

The isolated sperm heads were recovered from the $75 \%$ $(w / v)$ sucrose layer on the discontinuous sucrose gradients. The pellet obtained from the $75 \%(\mathrm{w} / \mathrm{v})$ sucrose layer contained $>95 \%$ of sperm heads and was free of significant contamination by sperm flagella (Fig. 2). Most of the sperm flagella were retained in the interface between the $35 \%(\mathrm{w} / \mathrm{v})$ and $68 \%(\mathrm{w} / \mathrm{v})$ sucrose layers.

\section{Isolation of subacrosomal proteins}

The acrosome and its attached cytoplasmic membrane (see Fig. 1) were completely detached by the Triton X-100 treatment (Fig. 3). The ultrastructural study revealed that the subacrosomal protein remnants were preserved and left over on the nuclear membrane after the Triton X-100 treatment (Fig. 3). The nucleus and its membrane remained intact. Subsequent $\mathrm{NaOH}$ extraction removed the remnants of the subacrosomal proteins from the isolated sperm heads.

\section{Composition of the subacrosomal proteins}

The SDS-PAGE analysis showed that the supernatant of the $\mathrm{NaOH}$ extraction, presumably containing the subacrosomal proteins, consisted of approximately ten polypeptide bands (lane SAP in Fig. 4). Within those bands, the 45, 38, 33 and $29 \mathrm{kDa}$ bands were the most prominent. Compared with polypeptide bands extracted from the sperm tail by Triton $\mathrm{X}$-100 (lane $\mathrm{T}$ in Fig. 4), the $33 \mathrm{kDa}$ polypeptide (lane SAP in Fig. 4) appeared unique to the $\mathrm{NaOH}$ protein extraction from the subacrosomal region.

\section{Immunolocalization of the $45 \mathrm{kDa}$ polypeptide}

A polyclonal antibody against the $45 \mathrm{kDa}$ polypeptide was produced. The polyclonal antibody reacted specifically with its respective band on the western blots (lane 1 in Fig. 5), although a very slight crossreactivity was detected on some other bands. Therefore, the polyclonal antibody was used for the immunolocalization of the $45 \mathrm{kDa}$ polypeptide on the tammar wallaby spermatozoa.

Immunofluorescent labelling on the sperm heads, the acrosomes of which had been stripped off to expose the subacrosomal region after the Triton X-100 incubation (Fig. 6a), showed that the anti- $45 \mathrm{kDa}$ antibody was restricted in its labelling in the subacrosomal region - a concavity on the anterior end of the nucleus (Fig. 6b). Immunofluorescent labelling was not found on the same region of the spermatozoa treated with the control serum.

Ultrastructural location of the $45 \mathrm{kDa}$ polypeptide was further confirmed by immunogold labelling on acrosomedetached sperm heads. The polyclonal antibody raised against 


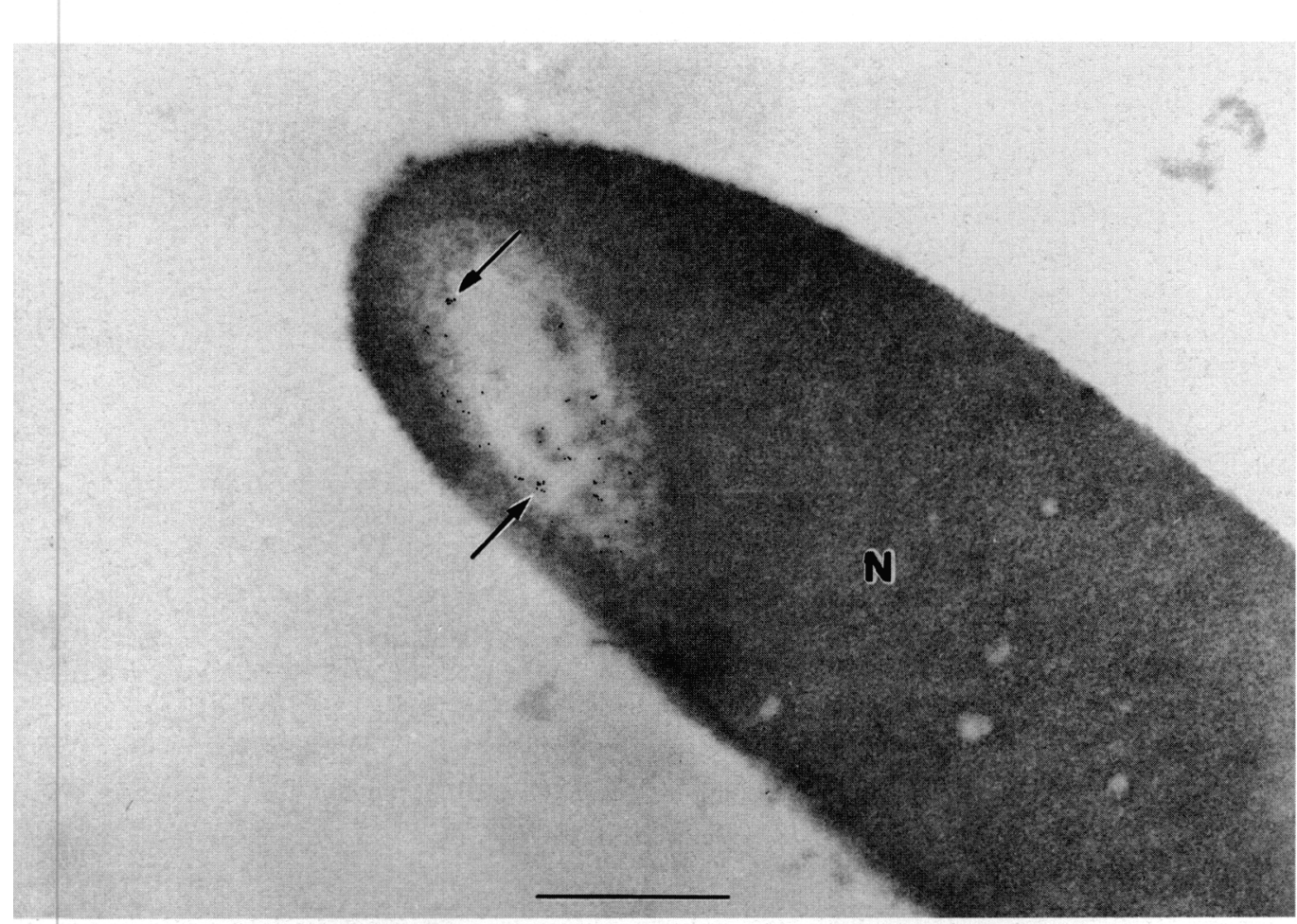

Fig. 7. Electron micrograph showing immunogold localization of the subacrosomal protein on an acrosomedetached tammar wallaby sperm head. Gold particles conjugated with the polyclonal antibody against the $45 \mathrm{kDa}$ subacrosomal polypeptide (arrows) strictly located in the concavity on the anterior end of the nuclear surface, where the acrosome had been lodged before detachment. N: nucleus. Scale bar represents $0.5 \mu \mathrm{m}$.
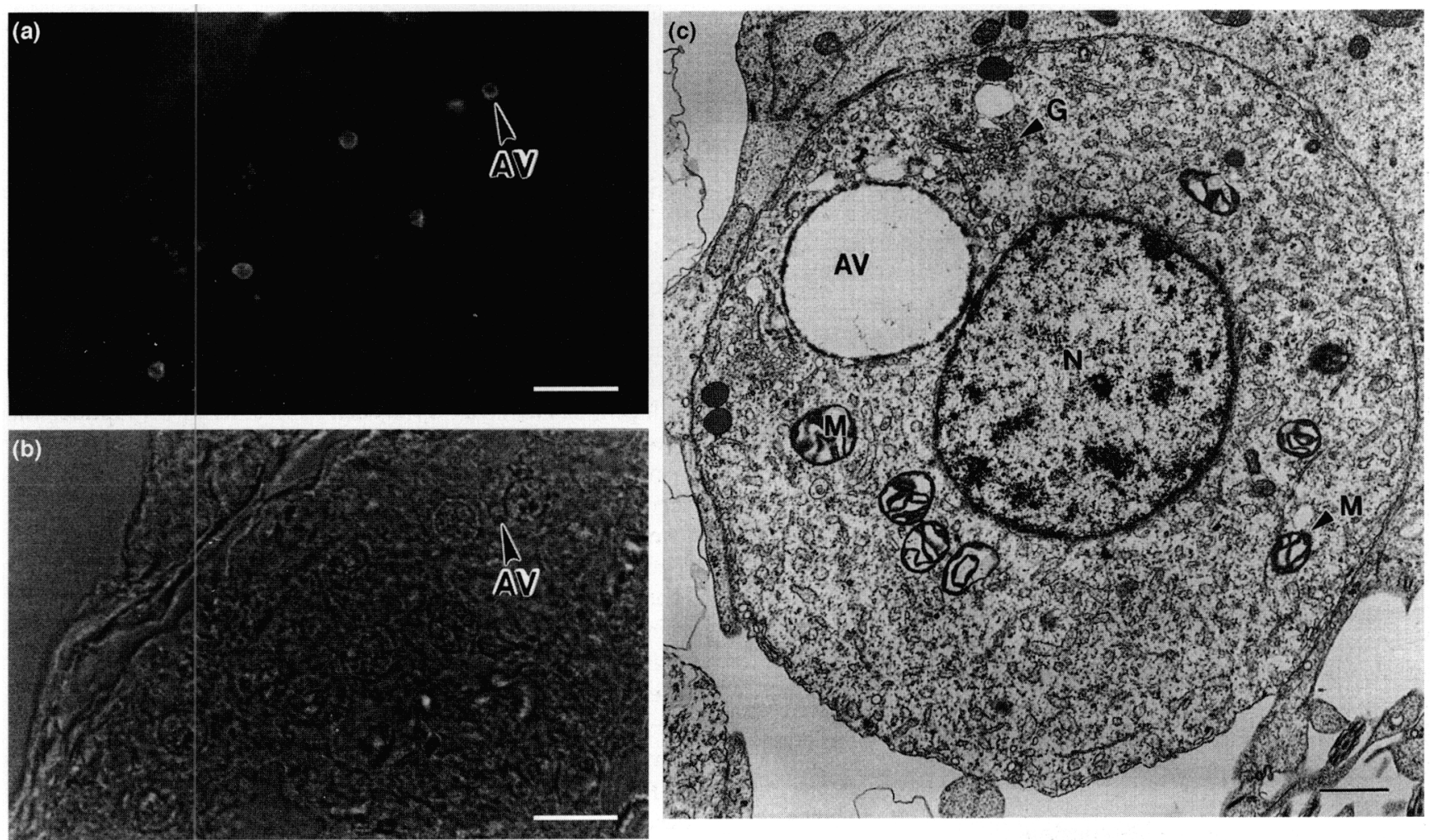

Fig. 8. Localization of the $45 \mathrm{kDa}$ subacrosomal polypeptide in step 3 spermatids in tammar wallaby testis. (a) Immunofluorescent image shows the $45 \mathrm{kDa}$ polypeptide located on the membrane of the formed acrosome vesicle (AV). (b) Phase-contrast images of the same testis section as (a). (c) Electron micrograph of a step 3 spermatid showing the position of the acrosomal vesicle (AV). G, Golgi body; M, mitochondria; $\mathrm{N}$, nucleus. Scale bars represent $(\mathrm{a}, \mathrm{b}) 20 \mu \mathrm{m}$, (c) $1 \mu \mathrm{m}$. 

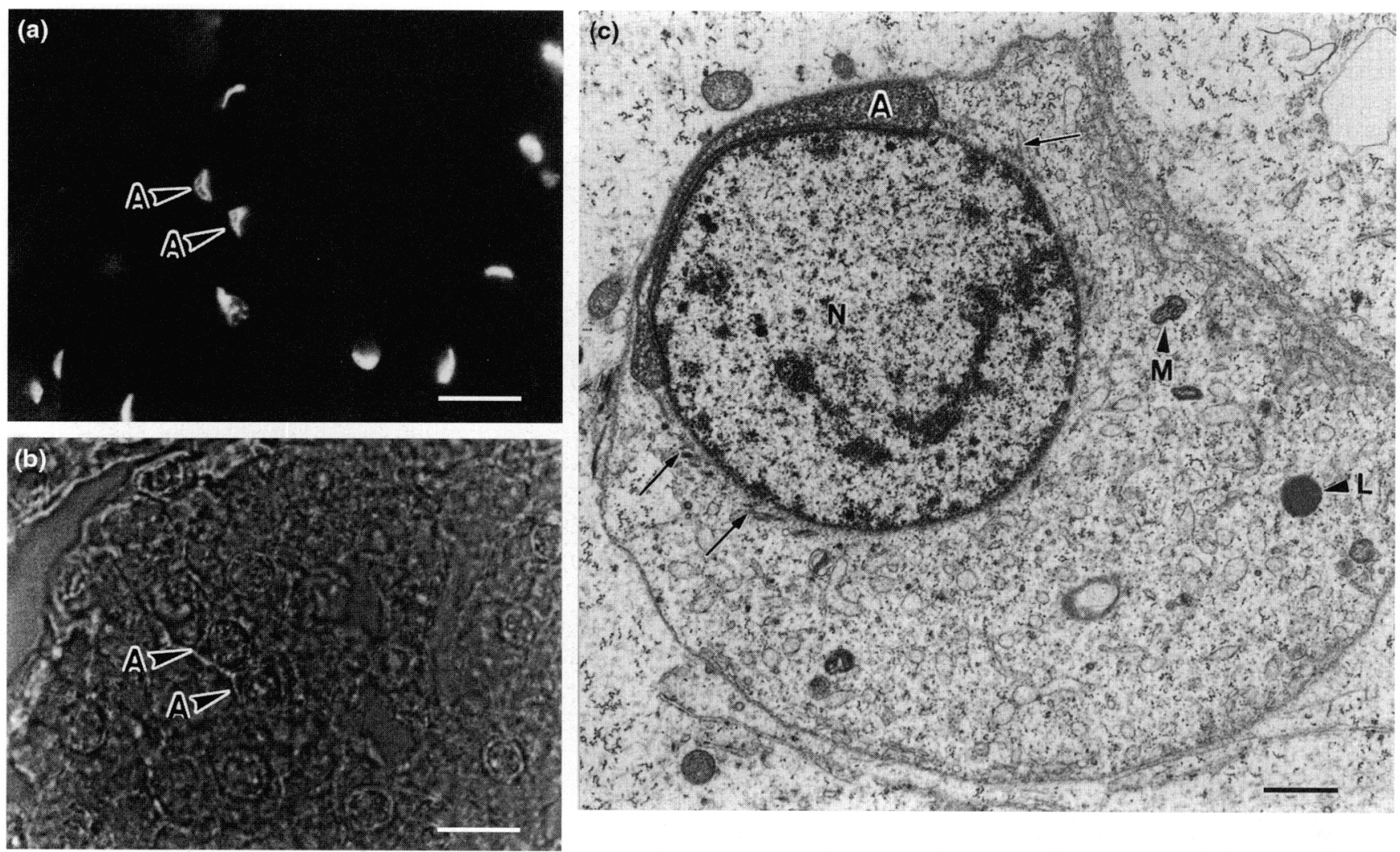

Fig. 9. Localization of the $45 \mathrm{kDa}$ subacrosomal polypeptide in step 6 spermatids in the tammar wallaby testis. (a) Immunofluorescent image shows the $45 \mathrm{kDa}$ polypeptide mainly associated with the acrosome membrane (A). (b) Phase-contrast images of the same testis section as (a). (c) Electron micrograph of a step 6 spermatid showing the acrosome $(A)$ as a cap-like structure covering one-third of the nucleus (N). L, lipid droplet; $\mathrm{M}$, mitochondria. Scale bars represent (a,b) $15 \mu \mathrm{m}$, (c) $1 \mu \mathrm{m}$.

the $45 \mathrm{kDa}$ polypeptide immunolabelled onto protein remnants on the subacrosomal region of the acrosome-detached nucleus (Fig. 7). However, there was no immunogold labelling found on the acrosome-detached sperm heads treated with the control serum.

Occurrence of the $45 \mathrm{kDa}$ polypeptide in the testis and the epididymis

In tammar wallaby testes, the $45 \mathrm{kDa}$ polypeptide was detected as early as at the step 3 spermatids by immunofluorescence (Fig. 8), and was located primarily on the membrane of the newly formed acrosome vesicle. This polypeptide was also found mainly on the acrosomal membrane of all older spermatids in the later stages of spermiogenesis (Fig. 9).

In the tammar wallaby epididymis, the $45 \mathrm{kDa}$ protein was labelled on the acrosomal region of the spermatozoa by FITC when spermatozoa passed through the caput (Fig. 10), corpus and cauda of the epididymis.

\section{Discussion}

Fractionation of the spermatozoa into the head and tail sections with a sonicator before extraction of proteins from the sperm head has been achieved in some eutherian species (rats: Jones et al., 1983; Oko and Clermont, 1988; Kim et al., 1995; bulls: Longo et al., 1988; Olson and Winfrey, 1988; Oko and Maravei, 1994; von Bülow et al., 1997). The present study demonstrated that the strength of sonication needed to decapitate tammar marsupial spermatozoa is much less than that used with eutherian mammals. This is possible because marsupial spermatozoa show a variety of unique structural changes during differentiation that give the sperm head a distinct dorsal and ventral character. While the acrosome is located on the dorsal surface of the nucleus, the tail of marsupial spermatozoa is inserted into a fossa in the mid-ventral surface of the nucleus; therefore, the nucleus can rotate through variable degrees, and form a $\mathrm{T}$ configuration between the nucleus and the tail (Bedford, 1991; Lin et al., 1997b). This unique morphological character weakens the connection of the head and tail of marsupial spermatozoa and makes the separation relatively easier than it is for the spermatozoa of eutherian species. Therefore, the strength and timeframe of the sonication used in the present study can be used as a reference point for other marsupial species.

The present study shows that the force of the centrifugation needed to purify the sperm head from the sonicated sperm suspension is also much less for tammar wallaby spermatozoa than it is for the spermatozoa of various eutherian species (Longo et al., 1987; Oko and Clermont, 1988; Olson and Winfrey, 1988; Oko and Maravei, 1994; von Bülow et al., 

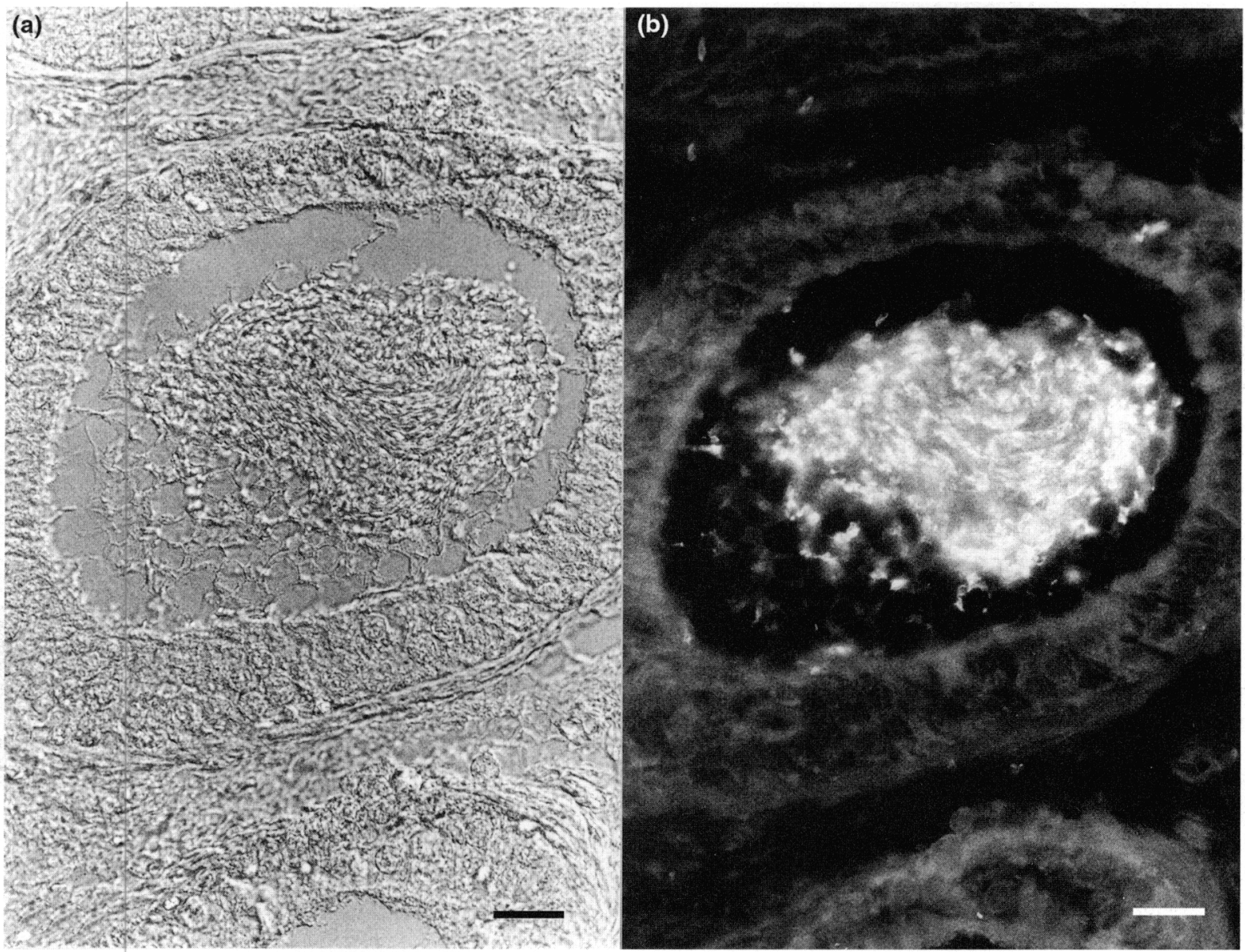

Fig. 10. (a) Phase-contrast and (b) fluorescent images of a cross-section of the caput epididymis of the tammar wallaby, showing the $45 \mathrm{kDa}$ polypeptide labelled on the sperm heads in the lumen of the epididymis. Scale bars represent $25 \mu \mathrm{m}$.

1997). A centrifugal force $>10$ times stronger than that used in the present study is required to achieve a purity of $>95 \%$ sperm heads in eutherian sperm separation if a similar three-step sucrose gradient is used (Pihlaja et al., 1973; de Curtis et al., 1986). For example, in rats, for the separation of the sperm heads, a centrifugation at $100000 \mathrm{~g}$ for $70 \mathrm{~min}$ with a sucrose gradient of 65,70 and $75 \%(\mathrm{w} / \mathrm{v})$ was required (Oko and Clermont, 1988; Kim et al. 1995). In bulls, a centrifugation of $100000 \mathrm{~g}$ for $90 \mathrm{~min}$ was required for the separation of the sperm head in a similar sucrose gradient (von Bülow ef al., 1997). The relatively low centrifugal force needed to separate the decapitated marsupial sperm heads from tails implies that there is a substantial difference in density and size (diameter of the particles) between marsupial sperm heads and tails. The difference in density and size between sperm heads and tails in eutherian spermatozoa may not be so marked as it is in marsupial spermatozoa.

The SDS-PAGE analysis showed that the subacrosomal region of tammar wallaby spermatozoa possessed four prominent polypeptide bands with molecular masses of $45,38,33$ and $29 \mathrm{kDa}$, respectively. A direct comparison of the protein composition of subacrosomal protein is difficult because of the different methods applied for the extraction. However, compared with the subacrosomal proteins extracted with Triton $\mathrm{X}-100$ and $\mathrm{NaOH}$ from eutherian spermatozoa (which usually also possess a series of prominent polypeptide bands), the molecular masses of the subacrosomal polypeptides extracted from the marsupial spermatozoa are in a similar range to those of eutherian species. For example, the six most prominent polypeptides recovered from the sub and post-acrosomal regions of rat spermatozoa have molecular masses ranging from 13 to $43 \mathrm{kDa}$ (Oko and Clermont, 1988). The molecular masses of the prominent subacrosomal polypeptides of the bull spermatozoa range from 15.5 to $60 \mathrm{kDa}$ (Oko and Marvei, 1994).

The subacrosomal polypeptide bands (the perinuclear theca proteins) appear variable among eutherian species (Oko and Clerment, 1991a,b; Jassim et al, 1993; Oko and Maravei, 1994). However, recent immunocytochemical studies have demonstrated that the epitopes of some polypeptides are shared among different species. Oko (1995) found that affinity-purified antibodies raised against the rat $15 \mathrm{kDa}$ and the bull $60 \mathrm{kDa}$ perinuclear theca peptides had interspecies immunocrossreactivities among the spermatozoa of rats, mice and bulls. This finding supports the idea that perinuclear theca proteins are similar in composition and conserved across eutherian species (see review Oko, 1995). At present, there are very few data on this aspect of marsupial subacrosomal proteins. It is not yet known whether the conservation of these proteins occurs between eutherian and marsupial species or among marsupial 
species, although the proteins have similar molecular masses and, possibly, similar functions.

The results of the immunofluorescence and immunogold labelling of the present study confirm that the extracted $45 \mathrm{kDa}$ polypeptide was originally located on the subacrosomal region of the ejaculated tammar wallaby spermatozoa. A preembedding method was used in the present study to maximize the immunoreactivity. This allowed the subacrosomal proteins to be exposed on the surface and to react to the polyclonal antibody before the spermatozoa were fixed by glutaraldehyde and embedded in Spurr's resin. The results show that the gold particles were labelled on the subacrosomal region, a concavity on the dorsal surface of the sperm nucleus, and prove that the $45 \mathrm{kDa}$ polypeptide is one of the subacrosomal proteins.

It is possible that the $45 \mathrm{kDa}$ polypeptides are not only located on the subacrosomal region but are also associated with the acrosome membrane. This suggestion is supported by immunofluorescent images that show the $45 \mathrm{kDa}$ polypeptide associated with the membrane of the newly formed acrosome vesicle in step 3 spermatids and other steps of older spermatids. It has been reported that acrosome formation in marsupials is one of the longest and most complex processes found in mammalian species (Lin et al., 1997b; Setiadi et al., 1997). On the testicular spermatozoa of tammar wallabies, a scoop shape of the acrosome is found that is completely different from the compact button shape of the acrosome in ejaculated spermatozoa. The shaping of the acrosome into its mature form is not complete until the spermatozoa reach the distal cauda of the epididymis. Many surface membranes are engulfed into the acrosomal matrix during this process. Therefore, the location of the isolated subacrosomal polypeptides in the present study can be associated with the movement of the acrosomal membrane during the formation of the acrosome as the spermatozoa pass through the epididymis.

In summary, subacrosomal proteins have been isolated from a marsupial species for the first time. The roles of these isolated proteins in marsupial fertilization need to be determined by further studies. The significance of the present study is not only in providing a better understanding of the protein biochemistry of marsupial spermatozoa, but also in the development of a procedure that can extract proteins from specific locations on marsupial spermatozoa. The similarity of spermatozoa anatomy between the wallaby and other marsupials, such as the brushtail possum, implies that this procedure could be applied effectively to other marsupial species with minor modification.

Special thanks to A. Harman for her assistance on the EM work. The authors appreciate the excellent discussions of the manuscript from R. Murdoch and D. Kay. This work was supported by a grant from the Co-operative Research Centre for Conservation and Management of Marsupials, Australia.

\section{References}

Bedford JM (1991) The coevolution of mammalian gametes. In A Comparative Overview of Mammalian Fertilization pp 3-35 Eds BS Dunbar and MG O'Rand. Plenum Press, New York

Carrera A, Gerton GL and Mass SB (1994) The major fibrous sheath polypeptide of mouse sperm: structural and functional similarities to the A-kinase anchoring proteins Developmental Biology 165 272-257

de Curtis I, Fumagalli G and Borgese N (1986) Purification and characterization of two plasma membrane domains from ejaculated bull spermatozoa Journal of Cell Biology 102 1813-1825
Fulcher KD, Mori C, Welch JE, O'Brien DA, Klapper DG and Eddy EM (1995) Characterization of Fsc I cDNA for a mouse sperm fibrous sheath component Biology of Reproduction 52 41-49

Harding HR, Carrick FN and Shorey CD (1979) Special features of sperm structure and function in marsupials. In The Spermatozoon: Maturation, Motility, Surface Properties and Comparative Aspects pp 289-303 Eds DW Fawcett and JM Bedford. Urban and Schwarzenberg, Baltimore-Munich

Harding HR, Woolley PA, Shorey CD and Carrick FN (1982) Sperm ultrastructure, spermiogenesis and epididymal sperm maturation in dasyurid marsupials: phylogenetic implications In Carnivorous Marsupials pp 659-673 Royal Zoological Society of New South Wales, Sydney

Hess H, Heid H and Franke WW (1993) Molecular characterization of mammalian cylicin, a basic protein of the sperm head cytoskeleton Journal of cell Biology 122 1043-1052

Jassim A, Foxon R, Purkis P, Gray A and AI-Zuhdi Y (1993) AJ-p90: a novel protein of the perinuclear theca in human sperm subacrosome journal of Reproductive Immunology 23 169-188

Jones R, von Glos KI and Brown CR (1983) Changes in the protein composition of rat spermatozoa during maturation in the epididymis Journal of Reproduction and Fertility 67 299-306

Kim YH, McFarlane JR, Almahbobi G, Stanton PG, Temple-Smith PD and de Kretser (1995) Isolation and partial charaterization of rat sperm tail fibrous sheath proteins and comparison with rabbit and human spermatozoa using a polyclonal antiserum Journal of Reproduction and Fertility 104 107-114

Laemmli UK (1970) Cleavage of structural proteins during assembly of the heads of bacteriophage T4 Nature $227680-685$

Lalli M and Clermont Y (1981) Structural changes of the head components of the rat spermatid during late spermiogenesis American Journal of Anatomy $160419-434$

Lin M, Harman A and Rodger JC (1997a) Morphological maturation of the acrosome during sperm transit through the epididymis of the tammer wallaby Proceedings of the 28th Annual Conference of the Australian Society for Reproductive Biology, Canberra p. 38

Lin M, Harman A and Rodger JC (1997b) Spermiogenesis and spermiation in a marsupial, the tammar wallaby (Macropus eugenii) Journal of Anatomy 190 377-395

Longo FJ, Krohne G and Franke WW (1987) Basic proteins of the perinuclear theca of mammalian spermatozoa and spermatids: a novel class of cytoskeletal elements Journal of Cell Biology 105 1105-1120

Longo FJ, Krohne G and Franke WW (1988) Basic proteins of the perinuclear theca of mammalian spermatozoa and spermatids: a novel class of cytoskeletal elements Journal of Cell Biology 105 1105-1120

Mate KE and Rodger JC (1991) Stability of the acrosome of the brush-tailed possum (Trichosurus vulpecula) and tammar wallaby (Macropus eugenii) in vitro and after exposure to conditions and agents known to cause capacitation or acrosome reaction of eutherian spermatozoa Journal of Reproduction and Fertility $9141-48$

Morales CR, Oko R and Clermont $Y$ (1994) Molecular cloning and developmental expression of a mRNA encoding the $27 \mathrm{kDa}$ outer dense fiber protein of rat spermatozoa Molecular Reproduction and Development 37 229-240

Oko R (1995) Developmental expression and possible role of perinuclear theca proteins in mammalian spermatozoa Reproduction, Fertility and Development 7 $777-797$

Oko $R$ and Clermont $Y$ (1988) Isolation, structure and protein composition of the perforatorium of rat spermatozoa Biology of Reproduction 39 673-687

Oko $R$ and Clermont $Y$ (1991a) Origin and distribution of perforatorial proteins during spermatogenesis of the rat: an immunocytochemical study Anatomical Record 230 498-501

Oko R and Clermont Y (1991b) Biogenesis of specialized cytoskeletal elements of rat spermatozoa Annals of the New York Academy of Sciences 637 203-233

Oko R and Maravei D (1994) Protein composition of the perinuclear theca of bull spermatozoa Biology of Reproduction 50 1000-1014

Oko R and Morales CR (1992) Molecular cloning and expression mRNAs encoding proteins of perforatorium, outer dense fibers and fibrous sheath of rat spermatozoa Molecular Biology of the Cell 3 Abstract 101a

Oko R and Morales CR (1994) A novel testicular protein, with sequence similarities to a family of lipid binding proteins, is a major component of the rat sperm perinuclear theca Developmental Biology 166 235-245

Olson GE and Winfrey VP (1988) Characterization of the postacrosomal sheath of bovine spermatozoa Gamete Research 20 329-342

Pihlaja DJ, Roth LE and Consigli RA (1973) Bovine sperm fractionation I. Selective degradation and segment separation Biology of Reproduction $\mathbf{8}$ $311-320$ 
Setiadi D, Lin M and Rodger JC (1997) Post-testicular development of spermatozoa of the tammar wallaby (Macropus eugenii) Journal of Anatomy 190 275-288

Temple-Smith P (1987) Sperm structure and marsupial phylogeny. In Possims and Oposums: Studies in Evolution pp 171-193 Ed. M Archer. Surrey Beatty and Royal Zoological Society of New South Wales, Sydney van Der Hoorn FS, Tarnasky HA and Nordeen SK (1990) A new rat gene RT\& is specifically expressed during spermatogenesis Developmental Biology 142 147-I54

von Bülow M, Rackwitz H-R, Zimbelmann R and Franke WW (1997) CP B3, a novel isoform of an actin-binding protein, is a component of the cytoskeletal calyx of the mammalian sperm head Experimental Cell Research 233 216-224 